\section{UCDNN}

LIBRARY
University of Connecticut OpenCommons@UConn

Department of Natural Resources and the

Department of Natural Resources and the

Environment Articles

Environment

July 2003

\title{
Stand Structure Governs the Crown Collisions of Lodgepole Pine
}

Mark Rudnicki

University of Connecticut, mark.rudnicki@uconn.edu

Victor J. Lieffers

Uldis Silins

Follow this and additional works at: https://opencommons.uconn.edu/nrme_articles

\section{Recommended Citation}

Rudnicki, Mark; Lieffers, Victor J.; and Silins, Uldis, "Stand Structure Governs the Crown Collisions of Lodgepole Pine" (2003). Department of Natural Resources and the Environment Articles. 1.

https://opencommons.uconn.edu/nrme_articles/1 


\title{
Stand structure governs the crown collisions of lodgepole pine
}

\author{
Mark Rudnicki, Victor J. Lieffers, and Uldis Silins
}

\begin{abstract}
We investigated tree sway and crown collision behavior of even-aged lodgepole pine (Pinus contorta Dougl. ex Loud. var. latifolia Engelm.) stands of different structure in Alberta, Canada, to examine how these factors might affect loss of leaf area as stands mature. The Two Creeks stand (TC) had high density and slender trees, while the Chickadee stand $(\mathrm{CH})$ had stout trees. The TC stand was then thinned (TCT) to reduce the stand density. For each stand, simultaneous tree sways of a group of 10 trees were monitored with biaxial clinometers during wind speed of $5 \mathrm{~m} / \mathrm{s}$ (canopy top). Crown collisions were reconstructed by combining sway displacement of individual trees with their respective crown dimensions. Comparing the sway statistics between stands with contrasting mean bole slenderness (TC and $\mathrm{CH}$ ) indicated that more slender trees have greater sway displacements, faster sway speeds, and a greater depth of collision. Disturbance by thinning increased sway displacements, sway speeds, and depth of collisions at TCT. Tree sway patterns were circular in shape and not aligned with wind direction, but patterns were elongated after thinning. This demonstrates the high frequency of crown collision experienced by stands with slender trees and supports the notion that crown collisions result in empty space between crowns of trees.

Résumé : Les auteurs ont étudié le balancement des arbres et la collision des cimes dans des peuplements équiennes de pin tordu latifolié (Pinus contorta Dougl. ex Loud. var. latifolia Engelm.) de différentes structures en Alberta, au Canada, afin d'examiner comment ces facteurs pouvaient influencer la perte de surface foliaire lorsque les peuplements arrivent à maturité. Le peuplement de Two Creeks (TC) possédait une densité élevée et des arbres élancés alors que celui de Chickadee $(\mathrm{CH})$ avait des arbres trapus. Le peuplement de TC a ensuite été éclairci (TCT) pour en réduire la densité. Dans chaque peuplement, le balancement simultané d'un groupe de 10 arbres a été suivi avec des clinomètres bi axiaux, lorsque la vitesse du vent au sommet du couvert était de $5 \mathrm{~m} / \mathrm{s}$. Les collisions des cimes ont été reconstituées en combinant le déplacement des arbres individuels avec leurs dimensions respectives de cime. La comparaison des statistiques d'oscillation entre des peuplements dont l'élancement des tiges diffère fortement indique que les arbres plus élancés subissaient des déplacements plus importants, des vitesses d'oscillation supérieures et une intensité de collision plus élevée. La perturbation par éclaircie a amplifié les déplacements, a augmenté leur vitesse et l'intensité des collisions dans le peuplement TCT. Les patrons de balancement étaient de forme circulaire et non alignés avec la direction des vents mais ont pris une forme plus allongée après l'éclaircie. Ceci démontre que la fréquence des collisions est élevée dans les peuplements avec des arbres élancés et appuie l'idée que les collisions des cimes conduisent à un espace non occupé entre la cime des arbres.
\end{abstract}

[Traduit par la Rédaction]

\section{Introduction}

Overstory canopy structure is one of the major factors controlling forest productivity and stand dynamics (Oliver and Larson 1996). The spatial variability of canopy leaf area due to clustering of foliage in the crowns of individual trees (Sampson and Smith 1993; Kucharik et al. 1999) and formation of canopy gaps (Runkle 1982, 1998) creates spatial het-

Received 4 April 2002. Accepted 7 February 2003. Published on the NRC Research Press Web site at http://cjfr.nrc.ca on 30 May 2003.

M. Rudnicki and V.J. Lieffers. ${ }^{1}$ Centre for Enhanced Forest Management, Department of Renewable Resources, 442 Earth Science Building, University of Alberta, Edmonton, ABT6G 2E3, Canada.

U. Silins. Centre for Enhanced Forest Management,

Department of Renewable Resources, 751 General Services

Building, University of Alberta, Edmonton, AB T6G 2H1,

Canada.

${ }^{1}$ Corresponding author (e-mail: vic.lieffers@ualberta.ca). erogeneity in light within and below the canopy. This variability in light transmission has been a central focus of stand dynamics research (Oliver and Larson 1996; Cescatti 1997); indeed, competition for light is considered the dominant mechanism driving changes in species composition and canopy structure. However, a poorly explored area of canopy structure is crown shyness or the empty space between crowns that is not attributable to tree mortality gaps (Putz et al. 1984). It has been assumed that empty spaces between crowns develop because lateral branches of the middle and lower crown are shaded by neighbors resulting in reduced growth (Umeki 1995; Chen et al. 1996; Cescatti 1997; Mäkelä 1997). However, an alternative hypothesis for the cause of crown shyness is direct physical interference from neighboring trees (Putz et al. 1984), where collisions of crowns during chronic wind events might abrade the branches, thereby creating an empty space between crowns.

Crown collisions during wind events have been implicated in damage or breakage of twigs (Jacobs 1954; Nobel 1981; Michalsky 1996; Aradóttir et al. 1997), loss of leaf area (Grier 1988; Foster and Boose 1992), and age-related forest 
Table 1. Mean dimensions of individual trees representing three stand structures of Pinus contorta var. latifolia.

\begin{tabular}{lllllll}
\hline Stand & DBH $(\mathrm{cm})$ & Height $(\mathrm{m})$ & $\begin{array}{l}\text { Slenderness } \\
(\mathrm{ht} / \mathrm{DBH})\end{array}$ & $\begin{array}{l}\text { Height of crown } \\
\text { centre }(\mathrm{m})\end{array}$ & $\begin{array}{l}\text { Density } \\
\text { (trees/ha) }\end{array}$ & $\begin{array}{l}\% \text { crown } \\
\text { closure }\end{array}$ \\
\hline $\mathrm{TC}^{a}{ }^{a}$ & 11.8 & 15.4 & 1.34 & 13.0 & 2150 & 40 \\
$\mathrm{TCT}^{b}$ & 13.4 & 16.0 & 1.23 & 13.3 & 1300 & 32 \\
$\mathrm{CH}^{c}$ & 18.1 & 13.9 & 0.79 & 10.3 & 1500 & 78 \\
\hline
\end{tabular}

decline (Gower et al. 1996; Ryan et al. 1997; Smith and Long 2001); however, surprisingly little mechanistic research has explored this process. Only a study by Long and Smith (1992) demonstrated the potential importance of crown abrasion by examining the breakage of artificial pickets inserted into crowns of pine trees.

In addition to wind speed, tree biomechanical properties and stand density affect the wind sway of individual trees (Petty and Swain 1985; Peltola and Kellomäki 1993) and, presumably, collisions of crowns (Gardiner 1995; Kerzenmacher and Gardiner 1998). Tree stiffness is determined by bole modulus of elasticity and the change in bole cross sectional area over its length (slenderness), with bole slenderness coefficient (tree height/diameter) being the main determinant of tree stiffness (Niklas 1992). Stand density (trees/ha) affects crown size (Jack and Long 1991), crown wind exposure (Peltola 1996), and mediates crown collisions directly by damping tree sways (White et al. 1976; Mayer 1987; Gardiner et al. 1997). Crown surface area and canopy exposure determine the amount of intercepted wind and, thus, the magnitude of wind loads.

Objectives of the study were to examine how stand density, crown width, tree slenderness coefficient, and wind speed affected frequency and intensity of crown collisions in lodgepole pine (Pinus contorta Dougl. ex Loud. var. latifolia Engelm.). We studied lodgepole pine because it typically regenerates in pure, even-aged stands, and it commonly exhibits crown shyness (Jack and Long 1991). We postulated that (1) more slender trees (less stiff) will experience more sway, leading to more crown collisions, and (2) more collisions lead to more abrasion, which results in more crown shyness. In this descriptive study, we quantified the first aspect of this conceptual model. We hypothesized that under similar wind conditions, stands with slender trees have a higher frequency and intensity of collisions than stout trees. To study changes in wind loading on crown collisions, we compared a stand with slender trees before and after thinning and a stout stand at two different wind speeds. We hypothesized that increased crown wind loads would result in higher collision frequencies and intensities and alter sway patterns.

\section{Materials and methods}

We studied two pine stands from a fire origin that were even aged, naturally regenerated, and unmanaged, located in the lower foothills of west central Alberta, Canada. The Two Creeks site (TC) $\left(54^{\circ} 11^{\prime} \mathrm{N}, 116^{\circ} 10^{\prime} \mathrm{W}\right)$ regenerated in 1954 and had a mean density of 2150 trees/ha, which includes an understory of Picea mariana (Mill.) BSP (black spruce) saplings (Table 1). The Picea mariana understory averaged $4 \mathrm{~m}$ tall and $7 \mathrm{~cm}$ diameter at breast height (DBH). Deadstanding and dying Pinus contorta were common ( $\sim 200$ per hectare in the lower part of the size distribution), providing evidence of self-thinning mortality. The TC site had a $5^{\circ}$ westerly slope with ground cover dominated by feathermosses and Ledum groenlandicum Oeder. The Chickadee site $(\mathrm{CH})$ originated in $1963\left(54^{\circ} 22^{\prime} \mathrm{N}, 116^{\circ} 28^{\prime} \mathrm{W}\right)$ and had a mean density of 1500 Pinus contorta trees/ha; trees were stout (Table 1). The $\mathrm{CH}$ site had an intermittent understory of Alnus spp. $\sim 3 \mathrm{~m}$ in height with an average $10^{\circ}$ westerly slope. The $\mathrm{CH}$ site showed no evidence of suppression mortality.

To quantify sway patterns and crown collisions of a group of lodgepole pine, we used techniques developed by Rudnicki et al. (2001). We chose 10 adjacent trees at each site that were representative of stand structural attributes, had a minimum distance of $1 \mathrm{~m}$ between stems, and no nearby tree-fall gaps (Table 1). Lateral crown extent of each tree was measured on eight $45^{\circ}$ vectors (from the ground), using a leveled, right-angle mirror for precise, vertical sighting "crown scope" (Rudnicki et al. 2001; Vales and Brunnel 1988). These measurements were used to create eight-sided polygons representing crown shape and area. To measure bole rotation (angular displacement from vertical) on each tree, biaxial clinometers (Applied Geomechanics Inc., California, U.S.A.) were installed at the base of the live crown, with readings recorded 10 times per second using a CR23X datalogger (Campbell Scientific, Utah, U.S.A.) (Rudnicki et al. 2001). A meteorological tower with anemometers mounted at midcanopy and canopy top height monitored wind speed in each stand. A 3-min running average of wind speed $>5 \mathrm{~m} / \mathrm{s}$ at the canopy top was used to trigger the data collection from clinometers. Long-term data on wind speeds collected near the study sites (BP Canada) ${ }^{2}$ showed that gusts (maximum speed in each hour) $>5 \mathrm{~m} / \mathrm{s}$ were common, with an hourly wind gust of this magnitude occurring in $~ 30 \%$ of the total hours and an hourly wind gust $>8 \mathrm{~m} / \mathrm{s}$ observed in $11 \%$ of the total hours. The highest recorded gust was $16.1 \mathrm{~m} / \mathrm{s}$. A sustained period of mean wind speed $>8 \mathrm{~m} / \mathrm{s}$, however, was rare for the area, since we were only able to collect these data once in over 2 years of observation. Dominant wind direction for the site was from $290^{\circ}$, and this was the approximate wind direction during data collection.

After 10 months of monitoring wind events, the TC site was thinned ( $1 \mathrm{ha}$ ) to remove the understory Picea mariana and smallest diameter Pinus contorta. Density of pine was

\footnotetext{
${ }^{2}$ Windfall gas plant air quality database. 1994-2000. BP Canada Energy Company. Public Affairs 240 - 4th Avenue SW Calgary, Alberta,
Canada.
} 
Table 2. Wind speeds and tree sway statistics for each structural type, with corresponding wind conditions used in collision analyses.

\begin{tabular}{|c|c|c|c|c|c|c|}
\hline \multirow[b]{2}{*}{ Stand } & \multirow[b]{2}{*}{$\begin{array}{l}\text { Mean top wind } \\
\text { speed }(\mathrm{m} / \mathrm{s})\end{array}$} & \multirow[b]{2}{*}{$\begin{array}{l}\text { Mean midcrown wind } \\
\text { speed }(\mathrm{m} / \mathrm{s})\end{array}$} & \multicolumn{2}{|c|}{$\begin{array}{l}\text { Crown sway speed } \\
(\mathrm{m} / \mathrm{s})\end{array}$} & \multicolumn{2}{|c|}{$\begin{array}{l}\text { Crown sway distance } \\
\text { (m) }\end{array}$} \\
\hline & & & Mean & Max. & Mean & Max. \\
\hline $\mathrm{TC}^{a}$ & 5.0 & 1.5 & $1.05(0.0058)$ & 6.18 & $0.60(0.0028)$ & 2.60 \\
\hline $\mathrm{TCT}^{b}$ & 5.1 & 4.2 & $1.38(0.0068)$ & 7.32 & $0.84(0.0034)$ & 3.04 \\
\hline $\mathrm{CH}^{c}$ & 5.1 & 1.1 & $0.29(0.0015)$ & 1.58 & $0.12(0.0005)$ & 0.47 \\
\hline $\mathrm{CH}$ (high wind) ${ }^{d}$ & 7.9 & 1.6 & $0.67(0.0053)$ & 3.58 & $0.25(0.0017)$ & 1.02 \\
\hline
\end{tabular}

Note: Total observation period and mean wind direction, respectively, are $57.9 \mathrm{~min}$ and $278^{\circ}$ for TC, $69.4 \mathrm{~min}$ and $281^{\circ}$ for TCT, $63.6 \mathrm{~min}$ and $308^{\circ}$ for $\mathrm{CH}$, and $20.2 \mathrm{~min}$ and $305^{\circ}$ for $\mathrm{CH}$ (high wind). Values in parentheses indicate standard error.

${ }^{a}$ Two Creeks.

"Two Creeks (thinned).

${ }^{c}$ Chickadee.

${ }^{d}$ Chickadee (high wind),

1300 stems/ha after the thinning, which created our third stand structural type (TCT). Three of the original sensored trees were removed in the thinning and replaced with three adjacent trees. The TCT site was monitored for an additional 9 months. The meteorological tower and sway monitoring apparatus were then relocated to the $\mathrm{CH}$ site, approximately $27 \mathrm{~km}$ southwest, for 8 more months.

We used approximately $60 \mathrm{~min}$ of sway data from each of the three stand structure types. The data set for each stand was combined from four or five periods of similar wind speed $(5 \pm 0.5 \mathrm{~m} / \mathrm{s})$, wind direction $\left(260^{\circ}-310^{\circ}\right)$, and air temperature $\left(>10^{\circ} \mathrm{C}\right)$ (Table 2). In addition, we recorded $20 \mathrm{~min}$ of sway data with a mean wind speed of $7.9 \mathrm{~m} / \mathrm{s}$ at the $\mathrm{CH}$ site (Table 2).

We estimated bole displacement from resting position by applying the stem flexure formula derived in Rudnicki et al. (2001) to the bole rotation data for all 10 trees at each time step (0.1 s). GIS software (Arc/Info) was used to reconstruct collisions by positioning crown polygons on their respective bole positions at each time step. Polygon overlap sizes and frequencies were quantified for all pairs of interacting tree crowns (Rudnicki et al. 2001). We reconstructed crown interactions for the 10 adjacent trees at the midcrown position of $13 \mathrm{~m}$ for the TC site before and after thinning and at the midcrown position of $10 \mathrm{~m}$ for the $\mathrm{CH}$ site. The midcrown position represents the widest lateral extent of the crowns and the crown centre of gravity (Dean and Long 1986). Polygon representations of the crowns were not altered to reflect any crown shape changes that may occur during stem deflection or collision (Hedden et al. 1995).

Midcrown displacement ( $\mathrm{m}$ ) from bole resting positions was calculated at each 0.1 -s time step, and tree sway speeds $(\mathrm{m} / \mathrm{s})$ were calculated between each successive time step for all 10 trees. Means for tree sway speed and distance were calculated from the entire dataset while maxima were calculated for each minute of data with the mean maxima reported.

Determining frequency of crown collisions required filtering associated crown overlaps and assigning them to a single collision. We developed two approaches of defining crown collisions. We defined a "disengagement" collision when polygons overlapped and then completely separated. Because crowns swaying in unison may abrade without separa- tion, we defined a second collision type. A "readvancement" collision was defined as follows: if two crowns were overlapping, a collision was tallied when the area of overlap increased to a maximum and then decreased. If the area of overlap increased again, even if crowns had not completely separated, a new collision was tallied. In both approaches, percent crown overlap was determined by selecting the area of maximum crown overlap from the collision event.

All crown collision statistics were based on data from the four central instrumented trees in each cluster, because these trees interacted primarily with other sensored trees. We calculated the mean crown overlap from the collisions of the four central trees with all instrumented trees. Maximum crown overlap was the average of the maximum crown overlap for the four central trees. The collision rate was calculated by summing the number of collisions, then dividing by number of minutes in the data set. Collision duration indicates mean time of overlap per collision.

We produced contour maps of the frequency density of bole sway locations of 10 trees in each stand type using bole location at the midcrown position using the GIS software (ArcView). We first plotted bole location $(x, y)$ for each time step (approximately 36000 per tree). Then, to create continuous contours for each tree, we used a smoothing technique (search radius of $5 \mathrm{~cm}$ ) that assigned the local frequency of bole occurrences to a grid of $1-\mathrm{cm}^{2}$ cells. The high wind data at $\mathrm{CH}$ was scaled to express relative density of bole positions for an equivalent 60 -min period.

\section{Results}

Crowns at the TC had a mean sway speed of $1.05 \mathrm{~m} / \mathrm{s}$, which was approximately three times the mean speed of $0.29 \mathrm{~m} / \mathrm{s}$ found at $\mathrm{CH}$ (Table 2). Maximum crown speed at TC was $6.18 \mathrm{~m} / \mathrm{s}$, which was nearly four times faster than at $\mathrm{CH}(1.58 \mathrm{~m} / \mathrm{s})$. Thinning resulted in greater stand wind penetration. There was a near tripling of mean wind speed at midcrown (relative to wind speeds at canopy top) after thinning at TC. As expected, mean sway speed also increased from 1.01 to $1.31 \mathrm{~m} / \mathrm{s}$, and the maximum sway speeds increased from 6.18 to $7.32 \mathrm{~m} / \mathrm{s}$ after thinning. When wind speed increased $(5.1-7.9 \mathrm{~m} / \mathrm{s})$ at the $\mathrm{CH}$ site, mean sway speed increased from 0.29 to $0.67 \mathrm{~m} / \mathrm{s}$, and maximum sway speed increased from 1.58 to $3.58 \mathrm{~m} / \mathrm{s}$. However, even at 
Table 3. Crown collision summaries for each data set using the "readvancement" and "disengagement" methods for four trees central in the group of 10 trees.

\begin{tabular}{|c|c|c|c|c|}
\hline \multirow[b]{2}{*}{ Stand } & \multicolumn{2}{|c|}{$\%$ crown overlap } & \multirow{2}{*}{$\begin{array}{l}\text { Mean collision } \\
\text { duration (s) }\end{array}$} & \multirow{2}{*}{$\begin{array}{l}\text { Collision rate (no. } \\
\text { per minute per tree }\end{array}$} \\
\hline & Mean & Max. & & \\
\hline \multicolumn{5}{|l|}{ Readvancement } \\
\hline $\mathrm{TC}^{a}$ & $23.2(1.00)$ & 65.9 & $0.36(0.125)$ & 73.1 \\
\hline $\mathrm{TCT}^{b}$ & $28.8(0.862)$ & 84.4 & $0.35(0.103)$ & 51.0 \\
\hline $\mathrm{CH}^{c}$ & $12.0(1.27)$ & 50.2 & $0.45(0.277)$ & 88.2 \\
\hline $\mathrm{CH}$ (high wind) ${ }^{d}$ & $14.8(1.87)$ & 65.0 & $0.37(0.304)$ & 132.3 \\
\hline \multicolumn{5}{|l|}{ Disengagement } \\
\hline $\mathrm{TC}^{a}$ & $23.3(0.993)$ & 65.9 & $0.48(0.276)$ & 47.4 \\
\hline $\mathrm{TCT}^{b}$ & $31.4(0.937)$ & 84.4 & $0.46(0.242)$ & 43.3 \\
\hline $\mathrm{CH}^{c}$ & $20.1(2.22)$ & 50.2 & $14.37(46.1)$ & 11.8 \\
\hline $\mathrm{CH}$ (high wind) ${ }^{d}$ & $16.0(2.20)$ & 65.0 & $0.68(1.67)$ & 63.0 \\
\hline
\end{tabular}

high wind speeds, the mean and maximum crown sway speeds at $\mathrm{CH}$ were still well below that of the slender trees at TC (Table 2).

Data on sway distance closely paralleled differences observed among stands and (or) treatments for sway speed. Mean sway distance of crowns was five times greater at TC $(0.60 \mathrm{~m})$ than at the more tapered $\mathrm{CH}$ stand $(0.12 \mathrm{~m})$; there was a similar difference for the maximum sway distances (2.6 and $0.47 \mathrm{~m}$, respectively) (Table 2 ). The mean sway distance at TC increased from 0.60 to $0.84 \mathrm{~m}$ after thinning (TCT), which probably reflected both greater wind penetration and more space between trees after thinning. Maximum sway distance for TCT increased from 2.60 to $3.04 \mathrm{~m}$ after thinning. At $\mathrm{CH}$, the increase in wind speed from 5.1 to $7.9 \mathrm{~m} / \mathrm{s}$ resulted in a doubling of mean sway distance $(0.12-$ $0.25 \mathrm{~m})$ and maximum sway distance $(0.47-1.02 \mathrm{~m})(\mathrm{Ta}-$ ble 2).

Collision duration and rate were strongly associated with differences in sway behavior among stands and treatments (Table 2, Table 3). The readvancement collision definition at TC resulted in a mean crown overlap of $23.2 \%$ and a maximum percent crown overlap of $65.9 \%$; these were both greater than at $\mathrm{CH}$ (12.0 and $50.2 \%$, respectively). Mean and maximum percent crown overlap increased after thinning, reflecting the increased wind loads and sway speeds. At $\mathrm{CH}$, both mean and maximum percent overlap of collisions increased from the period of moderate $(\sim 5.1 \mathrm{~m} / \mathrm{s})$ to high $(\sim 7.9 \mathrm{~m} / \mathrm{s})$ wind speed.

Collision statistics from the two collision definitions were generally similar, but we observed greater collision durations and lower collision rates for disengagement collisions than for the readvancement collisions (Table 3 ). This was especially evident in the $\mathrm{CH}$ stand when comparing periods of moderate $(\sim 5.1 \mathrm{~m} / \mathrm{s})$ to high $(\sim 7.9 \mathrm{~m} / \mathrm{s})$ wind speed, because relatively small displacements did not cause complete crown separation.

Contour maps of crown position frequency clearly illustrate the differences in sway patterns among the stand structures and wind speeds. The sway patterns for TC were mostly circular or elliptical in shape and had singular centroids near their respective bole locations (Fig. 1A). For TCT, all trees showed wider sway patterns and six trees had dual centroids (Fig. 1B). Tree sway patterns at the $\mathrm{CH}$ site had concentrated singular centroids near the bole resting position (Fig. 1C). The high wind increased the contour widths but did not appreciably change the contour shapes (Fig. 1D); single centroids remained near their respective bole locations. Even at the high wind speed $(7.9 \mathrm{~m} / \mathrm{s})$, the contour widths at $\mathrm{CH}$ were narrower than those of the slender TC stand at $5 \mathrm{~m} / \mathrm{s}$ (Figs. 1A and 1D).

\section{Discussion}

To our knowledge, this study is the first to demonstrate the high crown collision frequency experienced by some forest stands. The study also confirms the close association of crown collision frequency with stand attributes such as slenderness coefficient and density. The lower stiffness of trees at TC allowed crowns to easily be deflected in wind gusts compared with the stout trees at $\mathrm{CH}$. The collisions between the more slender trees at the TC site had much greater probability of damaging crowns or inhibiting shoot growth (2-5 times greater mean sway speeds, sway distances, depth of crown collisions, and higher frequency of disengagement crown collisions) than the stouter trees at CH. In higher density stands, slender trees appear to rely on a strategy of mutual support for stability and, consequently, suffer frequent and intense crown collisions, while the collisions at $\mathrm{CH}$ are a gentler rubbing of crowns. We suggest, therefore, that chronic and high speed crown collisions at TC probably explain the much greater crown shyness found at TC (40\% crown closure) than at $\mathrm{CH}$ (78\% crown closure). Because bole slenderness and stem density typically co-vary, mean stand slenderness coefficient is probably a good indicator of the potential for crown collisions and development of crown shyness due to crown abrasion.

The TCT stand had an increased distance between tree crowns and wind penetration into the canopy (midcrown 
Fig. 1. Frequency-density map to depict sway patterns at midcrown height of each of 10 trees in a group. (A) Two Creeks at winds of $5.0 \mathrm{~m} / \mathrm{s}$. (B) Two Creeks after thinning at winds of $5.1 \mathrm{~m} / \mathrm{s}$. (C) Chickadee at winds of $5.1 \mathrm{~m} / \mathrm{s}$. (D) Chickadee at winds of $7.9 \mathrm{~m} / \mathrm{s}$. All winds were from the westerly direction. Contour classes represent the mean frequency of the centre of the bole occupying a given cell location $\left(\mathrm{cm}^{2}\right)$ per hour. (There were a total of 36000 observations of bole position.) Contour shading tones are repeated with the outermost black shade always representing the lowest density class $\left(0.4-1\right.$ observation $\left.\cdot \mathrm{cm}^{-2} \cdot \mathrm{h}^{-1}\right)$. Subsequent inner rings represent increases in density class. Eight-sided polygons represent the extent of the crown at its resting position.

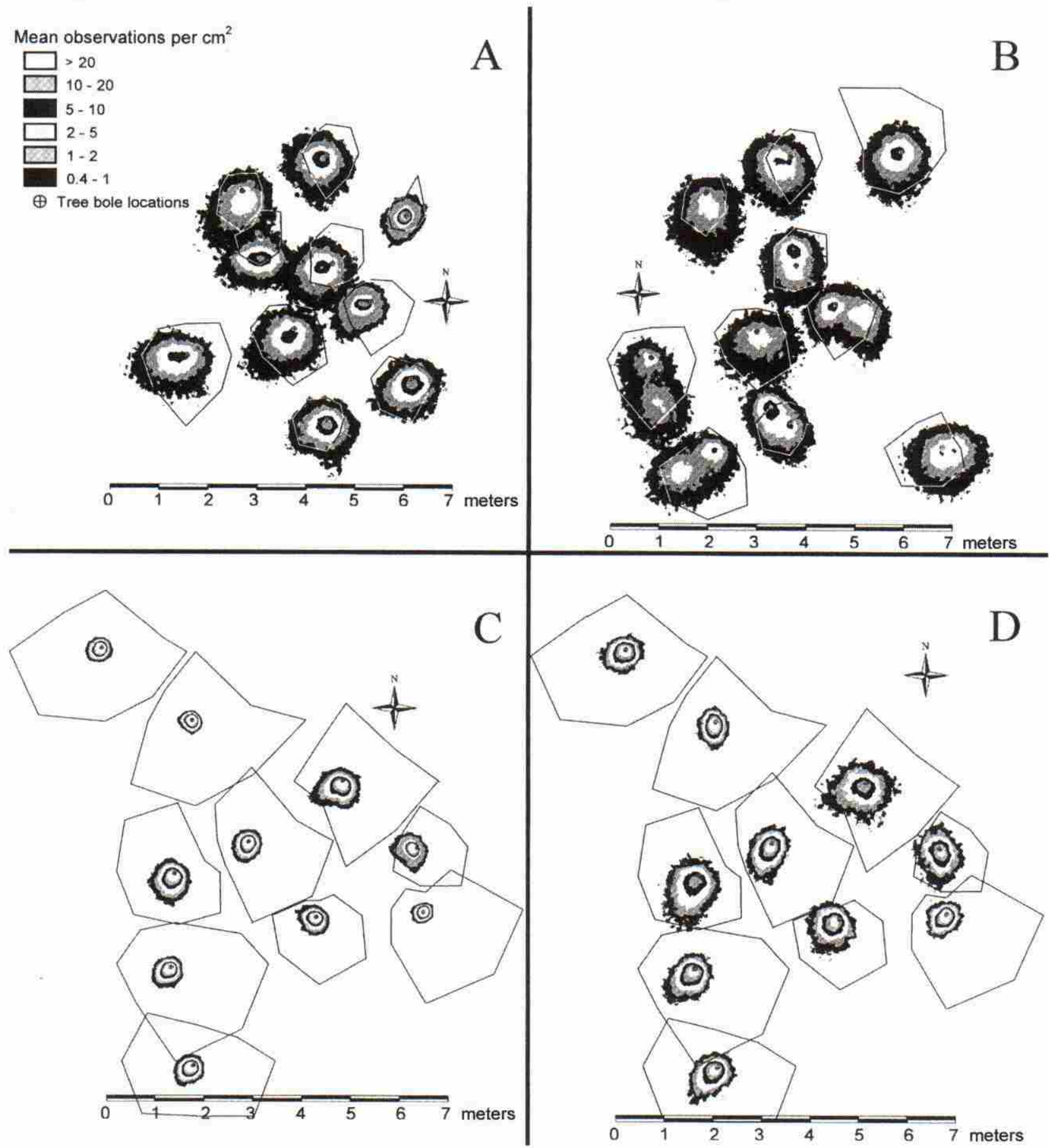

wind speed at TCT increased from 30 to $82 \%$ of the canopy top wind speed). Since it is likely the slender trees rely upon collisions for support, altering these factors also affected crown collisions and tree sway patterns. With the more distant neighbors at TCT, we observed increased mean sway speeds and sway distances with a concomitant increase in percent mean crown overlap. Thus, we believe that more intense collisions were experienced at TCT, which increases the probability of crown damage from collisions.

Sway patterns at TC were mostly circular or slightly elliptical, centered near the bole resting positions (Fig. 1A). Crown sway patterns were not aligned with or perpendicular 
to wind direction. A circular sway pattern centered on the resting position probably reflects minimum bending stresses on the bole. Furthermore, structural adaptation to maintain this pattern, such as growth of support roots or addition of compression wood on the bole in certain directions, are likely to develop gradually with tree and stand development (Telewski 1995). Most of the trees at the TCT site had altered (elongated) sway patterns containing two centroids (Fig. 1B). The thinning created a new crown sway regime by increasing wind penetration, changing wind flow behavior within the canopy, and increasing the intensity of swaydamping collisions. Hence, the back and forth motion of the trees after thinning probably reflects obsolete structural adaptations for the new wind and structural regime.

The probability of crown collisions and the pattern of tree sway at the $\mathrm{CH}$ site was compared at moderate $(5.1 \mathrm{~m} / \mathrm{s})$ and high $(7.9 \mathrm{~m} / \mathrm{s})$ wind speeds. The high wind event resulted in a tripling of sway speeds and sway distances compared with moderate wind speeds (Table 2 ), yet these values remained far lower than those at the more slender TC and TCT stands. Because the tapered trees at $\mathrm{CH}$ are mostly self-supporting, increased wind speeds resulted in a small $(2.8 \%)$ increase in mean crown overlap. The spatial patterns of tree sway were larger during high wind, yet remained similar in shape, suggesting that internal wind flow and collision dynamics remained consistent at both wind speeds (Figs. 1C and 1D).

Thigmomorphogenesis is the growth response of plants to mechanical stimuli that typically results in increased diameter and decreased length (Jaffe and Biro 1979; Rees and Grace 1980; Telewski and Jaffe 1986); in trees, the response to sway stimuli decreases the slenderness coefficient (Larson 1965; Neel and Harris 1971; Holbrook and Putz 1989). While this response enables more widely spaced trees to develop a self-supporting structure in response to mean wind loads, it can also serve to inhibit shoot extension (Michalsky 1996; Aradóttir et al. 1997). We suggest that the TC stand developed a high slenderness coefficient and crown shyness because a higher establishment density promoted crown collisions to dampen tree sway, thus the lack of bending stress reduced the allocation of carbon to radial growth. In contrast, lower density trees at $\mathrm{CH}$ were self-supporting with sway energies absorbed by the bole rather than dispersed through damaging crown collisions with neighbors. Thus, stands starting at low density develop stem biomechanical adaptations that inhibit the development of canopy shyness.

Damping of wind energy by collisions (Gardiner 1995) may prevent trees from toppling in most windstorms, but comes at a severe cost to the maintenance of leaf area because of branch breakage, twig and foliage loss, and loss of buds and future growth. While most of the abrasion damage probably occurs during the infrequent but strong windstorms on a site, chronic wind events are thought to inhibit lateral growth. Consequently, we suggest that both chronic and intense collisions limit where trees can forage for light, thereby rendering some areas of canopy space unusable. This may play an important role in the decline in stand leaf area index as stands age (Sampson and Smith 1993; Ryan et al. 1997; Smith and Long 2001), since bole slenderness typically increases after crown closure.

We believe the importance of crown collision on crown shyness may be particularly important in forests with cold winters. Because winters are long and there is increased brittleness of branches as air temperature declines below $0^{\circ} \mathrm{C}$ (Lieffers et al. 2001), increased potential for crown abrasion is likely (Robertson 1993). Crown collisions may be an important factor in the observations that $(i)$ declines in stand productivity with age are most severe in northern forests (Gower et al. 1996) and (ii) boreal forests have some of the most clumped canopies in the world (Kucharik et al. 1999).

\section{Acknowledgements}

Research was funded from the Natural Sciences and Engineering Research Council of Canada (NSERC), Canadian Forest Products, Millar Western Forest Products, Sunpine Forest Products, Weldwood of Canada, and Weyerhaeuser Canada. Thanks are extended to Sarah Lieffers, Vashti Thompson, and Justin Karst for their assistance in the field and to Tom Flesch for first installing a biaxial clinometer on a tree for displacement measures.

\section{References}

Aradóttir, A.L., Robertson, A., and Moore, E. 1997. Circular statistical analysis of birch colonization and the directional growth response of birch and black cottonwood in south Iceland. Agric. For. Meteorol. 84: 179-186.

Cescatti, A. 1997. Modelling the radiative transfer in discontinuous canopies of asymmetric crowns. I. Model structure and algorithims. Ecol. Model. 101: 263-274.

Chen, H.Y.H., Klinka, K., and Kayahara, G.J. 1996. Effects of light on growth, crown architecture, and specific leaf area for naturally established Pinus contorta var. latifolia and Pseudotsuga menziesii var. glauca saplings. Can. J. For. Res. 26: 1149-1157.

Dean, T.J., and Long, J.N. 1986. Validity of constant-stress and elastic-instability principles of stem formation in Pinus contorta and Trifolium pratense. Ann. Bot. 58: 833-840.

Foster, D.R., and Boose, E.R. 1992. Patterns of forest damage resulting from catastrophic wind in central New England, U.S.A. J. Ecol. 80: 79-98.

Gardiner, B.A. 1995. The interactions of wind and tree movement in forest canopies. In Wind and trees. Edited by M.P. Coutts and J. Grace. Cambridge University Press, Cambridge, U.K. pp. 41-59.

Gardiner, B.A., Stacey, G.R., Belcher, R.E., and Wood, C.J. 1997. Field and wind tunnel assessments of the implications of respacing and thinning for tree stability. Forestry, 70(3): 233-252.

Gower, S.T., McMurtrie, R.E., and Murty, D. 1996. Aboveground net primary production decline with stand age: potential causes. Trees, 11: $378-382$.

Grier, C.C. 1988. Foliage loss due to snow, wind, and winter drying damage: its effects on leaf biomass of some western conifer forests. Can. J. For. Res. 18: 1097-1102.

Hedden, R.L., Fredricksen, T.S., and Williams, S.A. 1995. Modelling the effect of crown shedding and streamlining on the survival of loblolly pine exposed to acute wind. Can. J. For. Res. 25: 704-712.

Holbrook, N.M., and Putz, F.E. 1989. Influence of neighbors on tree form: effects of lateral shade and prevention of sway on the allometry of Liquidambar styraciflua (sweet gum). Am. J. Bot. 76: $1740-1749$.

Jack, S.B., and Long, J.N. 1991. Analysis of stand density effects on canopy structure: a conceptual approach. Trees, 5: 44-49.

Jacobs, M.R. 1954. The effect of wind sway on the form and development of Pinus radiata D. Don. Aust. J. Bot. 2: 35-51. 
Jaffe, M., and Biro, R. 1979. Thigmomorphogenesis: the effect of mechanical perturbation on the growth of plants, with special reference to anatomical changes, the role of ethylene, and interaction with other environmental stresses. In Stress physiology in crop plants. Edited by H. Mossel and R.C. Staples. John Wiley \& Sons Inc., New York. pp 26-59.

Kerzenmacher, T., and Gardiner, B.A. 1998. A mathematical model to describe the dynamic response of a spruce tree to the wind. Trees, 12: 385-394.

Kucharik, C.J., Norman, J.M., and Gower, S.T. 1999. Characterization of radiation regimes in non-random forest canopies; theory, measurements, and a simplified modeling approach. Tree Physiol. 19: $695-706$.

Larson, P.R. 1965. Stem form of young Larix as influenced by wind and pruning. For. Sci. 11(4): 413-423.

Lieffers, S.M., Lieffers, V.J., Silins, U., and Bach, L. 2001. Effects of cold temperatures on breakage of lodgepole pine and white spruce twigs. Can. J. For. Res. 31: 1650-1653.

Long, J.N., and Smith, F.W. 1992. Volume increment in Pinus contorta var. latifolia: the influence of stand development and crown dynamics. For. Ecol. Manage. 53: 53-62.

Mäkelä, A. 1997. A carbon balance model of growth and selfpruning in trees based on structural relationships. For. Sci. 43(1): 7-24.

Mayer, H. 1987. Wind-induced tree sways. Trees, 1: 195-206.

Michalsky, A.J. 1996. An investigation of mechanical abrasion in saplings of sugar maple (Acer saccharum Marsh.). M.S. thesis, York University, Toronto, Ont.

Neel, P.L., and Harris, R.W. 1971. Motion-induced inhibition of elongation and induction of dormancy in Liquidambar. Science (Washington, D.C.), 173: 58-59.

Niklas, K.J. 1992. Plant biomechanics: an engineering approach to plant form and function. The University of Chicago Press, Chicago, IIl.

Nobel, P.S. 1981. Wind as an ecological factor. In Responses to the physical environment. Edited by O.L. Lange, P.S. Nobel, C.B. Osmund, and H. Ziegler. Springer-Verlag GmbH \& Co. KG, Berlin. pp. 475-500.

Oliver, C.D., and Larson, B.C. 1996. Forest stand dynamics. McGraw-Hill, New York.

Peltola, H. 1996. Swaying of trees in response to wind and thinning in a stand of Scots pine. Agric. For. Meteorol. 90: 187-194.
Peltola, H., and Kellomäki, S. 1993. A mechanistic model for calculating windthrow and stem breakage of Scots pines at stand edge. Silva Fenn, 27(2): 99-111.

Petty, J.A., and Swain, C. 1985. Factors influencing stem breakage of conifers in high winds. Forestry, 58(1): 75-84.

Putz, F.E., Parker, G.G., and Archibald, R.M. 1984. Mechanical abrasion and intercrown spacing. Am. Midl. Nat. 112: 24-28.

Rees, D.J., and Grace, J. 1980. The effects of shaking on extension growth of Pinus contorta Douglas. Forestry, 53: 155-166.

Robertson, A. 1993. Effects of wind on boreal forests. In Forest development in cold climates. Edited by J. Alden. Plenum Press Corporation, New York. pp. 203-225.

Rudnicki, M., Silins, U., and Lieffers, V.J. 2001. Measure of simultaneous tree sways and estimation of crown interactions among a group of trees. Trees, 15: 83-90.

Runkle, J.R. 1982. Patterns of disturbance in some old-growth mesic forests of eastern North America. Ecology, 63: 533-546.

Runkle, J.R. 1998. Changes in southern Appalachian canopy tree gaps sampled thrice. Ecology, 79: 1768-1780.

Ryan, M.G., Binkley, D., and Fownes, J.H. 1997. Age-related decline in forest productivity: pattern and process. Adv. Ecol. Res. 27: $213-261$.

Sampson, D.A., and Smith, F.W. 1993. Influence of canopy architecture on light penetration in lodgepole pine (Pinus contorta var. latifolia) forests. Agric. For. Meteorol. 64: 63-79.

Smith, F.W., and Long, J.N. 2001. Age-related decline in forest growth: an emergent property. For. Ecol. Manage. 144: 175-181.

Telewski, F.W. 1995. Wind-induced physiological and developmental responses in trees. In Wind and trees. Edited by M.P. Coutts and J. Grace. Cambridge University Press, Cambridge, U.K. pp. 237-263.

Telewski, F.W., and Jaffe, M.J. 1986. Thigmomorphogenesis: field and laboratory studies of Abies fraseri in response to wind or mechanical perturbation. Plant Physiol. 66: 211-218.

Umeki, K. 1995. Modeling the relationship between the asymmetry in crown display and local environment. Ecol. Model. 82: 11-20.

Vales, D.J., and Bunnel, F.L. 1988. Comparison of methods for estimating forest overstory cover. I. Observer effects. Can. J. For. Res. 18: 606-609.

White, R.G., White, M.F., and Mayhead, G.J. 1976. Measurement of the motion of trees in two dimensions. Institute of Sound and Vibration Research, University of Southhampton, Highfield, Southhampton, U.K. Tech. Rep. 86. 
Copyright $@ 2003$ EBSCO Publishing 